Endocrinol. Japon. 1988, 35 (1), 165-170

NOTE

\title{
A Case of Active Acromegaly with Reduced Height and Type 1 Renal Tubular Acidosis
}

\author{
TOSHIHIDE YAMAMOTO
}

Kishiwada Tokushukai Hospital, Kishiwada, Osaka, Japan

\begin{abstract}
A 41-year-old man with acromegaly was suffering from chronic, progressive backache and aware of reduction in his body height. Endocrine studies revealed increased glucose non-suppressible serum growth hormone $(\mathrm{GH})$ and serum prolaction (PRL). Pituitary microadenoma was detected by a computerized axial tomogram and subsequently resected by trans-sphenoidal adenomectomy. The tumor proved to be a mixed GH- and PRL-secreting adenoma by electron microscopy and immunoperoxidase staining. Concurrent investigation of backache and reduced height disclosed markedly reduced radiodensity of the spinal bones, bilateral nephrocalcinosis, and hypercalciuria, which were ascribed to renal tubular acidosis (RTA) demonstrated by reduced urinary excretion of acids and insufficient reduction of urinary $\mathrm{pH}$ following oral administration of ammonium chloride. From the analogy to certain endocrinopathies, it appears likely that enhanced calcium metabolism and resultant hypercalciuria due to excses GH and PRL have led to the development of RTA, which further enhanced calciuria. Such enhanced calcium metabolism and consequent hypercalicuria conceivably led to accelerated demineralization of the spine and resulted in the reduced height of this patient in his early forties.
\end{abstract}

The excessive secretion of growth hormone $(\mathrm{GH})$ causes acromegaly or gigatism depending on the age of onset. Reduction of height occurs infrequently in elderly patients with a long standing illness (Whitehead et al., 1982). The present reports deals with a patient in his early forties with acromegaly who complained of chronic, disabling backache and reduced height. He had in-

Received April 30, 1987

Please direct all correspondence to: TOSHIHIDE YAMAMOTO, M. D. Kishiwada Tokushukai Hospital 4-22-38 Isonokami-cho, Kishiwada, Osaka 596, Japan creased serum GH and prolactin (PRL), hypercalciuria, decreased radiodensity of the spine and pelvic bones, and bilateral nephrocalcinosis. The resected pituitary tumor was histologically determined as a mixed GH- and PRL-secreting tumor. Further studies disclosed normal arterial blood gas analysis and impaired urinary acidification, which was consistent with type 1 renal tubular acidosis (RTA-1). The role of mixed GH- and PRL-secreting pituitary adenoma and RTA-1 in the pathogenesis of advanced bone demineralization is discussed. 


\section{Case Summary}

41-year-old man came to our clinic with chronic, progressively disabling backache accompanied by a gradual reduction of his height for about a year. His height was $155 \mathrm{~cm}$ (previously $162 \mathrm{~cm}$ ), with an $82 \mathrm{~cm}$ the lower segment, and $162 \mathrm{~cm}$ arm span. The trunk was stocky with a slight increase in physiologic thoracic kyphosis. The blood pressure was $140-160 \mathrm{mmHg}$ systolic and $80-100 \mathrm{mmHg}$ diastolic. Acromegalic feature and enlarged hands and feet were observed, which he reported as having for about 10 years. The urine glucose and protein test results were negative. Microscopic hematuria was occasionally noticed. The complete blood counts were normal. The serum urea $\mathrm{N}$ concentration was 18.0, creatinine 1.1 and uric acid $5.2 \mathrm{mg} / \mathrm{dl}$ (mean of 4 determinations). The serum sodium, potassium and chloride concentrations were $141.4,3.6$ and $103.8 \mathrm{mEq} / \mathrm{L}$ (mean of 7 determinations). The endogenous creatinine clearance was $79.9 \mathrm{ml} / \mathrm{min} / 1.73 \mathrm{M}^{2}$. The urinary excretion of beta-2 microglobulin was $620 \mu \mathrm{g} /$ day (normals, $<350 \mu \mathrm{g}$ ). The plasma renin activity in the supine positition was $0.42 \mathrm{ng} / \mathrm{ml} / \mathrm{h}$ and the simultaneous plasma aldosterone concentration $45.2 \mathrm{pg} / \mathrm{ml}$. The serum concentrations of calcium, inorganic phosphate and magnesium were $4.42 \mathrm{mEq} /$ $\mathrm{L}, 4.20 \mathrm{mg} / \mathrm{dl}$, and $1.39 \mathrm{mEq} / \mathrm{L}$ (mean of 7 determinations). The urinary excretion of calcium and magnesium on a regular hospital diet (calcium content of $c a .13 \mathrm{mM} /$ day) was $8.7,3.9 \mathrm{mM} /$ day (mean for 3 days). The serum alkaline phosphatase activity was 7.0 to 9.0 (King-Armstrong unit). The serum concentration of parathyroid hormone found by a carboxy-terminal specific radioimmunoassay (RIA) was 0.3 and $0.4 \mathrm{ng} / \mathrm{ml}$ (normals, $<0.5 \mathrm{ng} / \mathrm{ml}$ ) and the serum calcitonin level by its RIA was 29 and $58 \mathrm{ng} / \mathrm{ml}$ (normals, $<165 \mathrm{ng} / \mathrm{ml}$ ).

Radiologic studies revealed a double- floored sella turcica with thinning of the posterior clinoid, bilateral nephrocalcinosis with nephrolithiasis, markedly reduced bone density of the spine and pelvic bones and modest flattening of the lumbar vertebrae. A microadenoma with a maximum diameter of $5 \mathrm{~mm}$ was detected inside the sella turcica by computerized axial tomography. The basal serum growth hormone $(\mathrm{GH})$ level was 8.5 to $17 \mathrm{ng} / \mathrm{ml}$. The $\mathrm{GH}$ level was not suppressed by oral glucose loading and showed exaggerated response to combined insulin-TRH-LH-RH injection. Serum prolactin (PRL) was also increased and further augmented following stimulation (Table 1). Fasting serum glucose, thyroid and adrenocortical hormones were normal. The secretion of the anterior pituitary hormones other than GH and PRL remained intact. The patient underwent a transsphenoidal adenomectomy. The histology of the excised tissue was an adenoma consisting of both eosinophilic and chromophobe cells. Two kinds of cells were identified in electron-micrographs, i. e. a densely granulated cell with well-developed rough endoplasmic reticulum and Golgi apparatus, and a sparcely granulated cell with less prominent reticulum and Golgi apparatus. The presence of GH and PRL in their cytoplasm was confirmed by immunoperoxidase stainings. When the reserve of the anterior pituitary was tested by the combined stimuli 3 months after the operation, the response of $\mathrm{GH}$ and PRL was still abnormal while the rest remained intact, $i$. e. serum $\mathrm{GH}$ was normal before and markedly augmented after the stimulation and the serum PRL was increased before and further augmented after the stimulation (Table 1). He has been treated with bromocriptine, $5.0 \mathrm{mg} / \mathrm{day}$, and oral supplementation of alkali and calcium since the study. Since then, the baseline serum level of $\mathrm{GH}$ and PRL remained in the normal range. Aberrant $\mathrm{GH}$ response to TRH injection gradually ameliorated in the 
subsequent period of observation up to 24 months.

\section{Studies of Urinary Acidification}

The urinary acidification was evaluated by [1] reduction of urinary $\mathrm{pH}$ after oral administration of ammonium chloride, and [2] quantitation of daily excretion of acids in urine according to the protocols described below. Both studies were carried out without prior dietary restriction. The timed urine samples were collected in jars containing toluene and liquid paraffin. The $\mathrm{pH}$ was measured with a glass electrode. The titratable acidity was quantitated by titrating aliquots of urine with $1 / 20 \mathrm{~N} \mathrm{NaOH}$ to $\mathrm{pH} 7.40$ and ammonium by a colorimetric assay (Okuda et al., 1965). The bicarbonate concentration in urine was calculated from total $\mathrm{CO}_{2}$ measured by $\mathrm{CO}_{2}$ electrode, $\mathrm{pH}$, $\mathrm{Na}^{+}$, and $\mathrm{K}^{+}$concentrations according to the following formulae:

$$
\begin{gathered}
\mathrm{pH}=\mathrm{pK}+\log \frac{\mathrm{HCO}_{3}^{-}}{\mathrm{H}_{2} \mathrm{CO}_{3}} \\
\text { total } \mathrm{CO}_{2}=\mathrm{HCO}_{3}{ }^{-}+\mathrm{H}_{2} \mathrm{CO}_{3} \\
\mathrm{pK}=6.33-0.5 \sqrt{\mathrm{Na}^{+}+\mathrm{K}^{+}} \quad(\text { Broyer, 1977) }
\end{gathered}
$$

\section{[1] $\mathrm{pH}$ reduction after ammonium chloride administration (Table 2)}

After a basal urine sample was obtained, ammonium chloride of $0.1 \mathrm{~g} / \mathrm{kg}$ was given p. $o$. and periodic urine samples were collected for 5 or 6 hours to measure the $\mathrm{pH}$. Arterial blood was drawn at 0, 2, 4 hours to measure $\mathrm{pH}, \mathrm{PaO}_{2}$ and $\mathrm{PaCO}_{2}$. The study was carried out twice, $i$. e. in the first post-operative month as well as in the 25 th month after the operation. Following the ingestion of ammonium chloride, the urine $\mathrm{pH}$ was reduced at best to 6.0 while the arterial $\mathrm{pH}$ was reduced to 7.34 and bicarbonate to $18.0 \mathrm{mEq} / \mathrm{L}$. 
Table 2. Ammonium Chloride Test

\begin{tabular}{|c|c|c|c|c|c|c|c|c|}
\hline & & $0 \mathrm{~h}$ & $1 \mathrm{~h}$ & $2 \mathrm{~h}$ & $3 \mathrm{~h}$ & $4 \mathrm{~h}$ & $5 \mathrm{~h}$ & $6 \mathrm{~h}$ \\
\hline First study & Urine & & & & & & & \\
\hline & $\mathrm{pH}$ & 6.16 & 6.60 & 6.86 & 6.62 & 6.63 & 6.43 & \\
\hline \multirow[t]{3}{*}{1 month post-op. } & Arterial blood & & & & & & & \\
\hline & $\mathrm{pH}$ & 7.42 & & 7.38 & & 7.38 & & \multirow{7}{*}{6.18} \\
\hline & Bicarbonate & 23.4 & & 19.5 & & $19.3(\mathrm{mEq} / \mathrm{L})$ & & \\
\hline Second study & Urine & & & & & & & \\
\hline & $\mathrm{PH}$ & 6.06 & & 6.00 & & 6.25 & & \\
\hline \multirow{3}{*}{25 months post-op. } & Arterial blood & & & & & & & \\
\hline & PH & 7.42 & & 7.34 & & 7.38 & & \\
\hline & Bicarbonate & 22.9 & & 18.0 & & $19.6(\mathrm{mEq} / \mathrm{L})$ & & \\
\hline
\end{tabular}

$\mathrm{NH}_{4} \mathrm{Cl}(0.1 \mathrm{~g} / \mathrm{kg})$ administered $p . o$. at $0 \mathrm{~h}$ after urine sample obtained.

\section{[2] Daily excretion of acids in urine}

The daily excretion of acids in urine was estimated by quantitating $\mathrm{pH}$, titratable acidity, ammonium, and bicarbonate for 3 days. Net acid output was calculated as the sum of titratable acidity and ammonium minus bicarbonate. The results were compared with those of 18 normal volunteers 'taking a regular hospital diet. The $\mathrm{pH}$, titratable acidity, ammonium, bicarbonate, and net acid output were $6.67,6.30$ $\mathrm{mEq}, \quad 39.8 \mathrm{mEq}, \quad 36.5 \mathrm{mEq}$, and $6.7 \mathrm{mEq}$ (mean of determinations) while those of the normal subjects were $6.14 \pm 0.07$ (mean $\pm \mathrm{SE}), 17.5 \pm 1.6 \mathrm{mEq}, 83.5 \mathrm{mEq}, 16.8 \pm 3.1$ $\mathrm{mEq}$, and $79.5 \pm 14.5 \mathrm{mEq} /$ day, respectively. The excretion of titratable acidity and ammonium ion appeard reduced while bicarbonate loss in urine was increased. The urinary loss of bicarbonate with reference to the endogenous creatinine clearance was calculated to be $0.4 \mu \mathrm{M} / \mathrm{ml}$ glomerular filtration rate, or $1.5 \%$ of the filtered bicarbonate, which was consistent with type 1 renal tubular acidosis (RTA-1).

\section{Discussion}

This patient was clinically considered to have active acromegaly with typical clinical findings and increased glucose non-suppres- sible serum GH due to a pituitary adenoma. The adenoma was pathologically demonstrated to be a mixed GH- and PRL-secreting tumor (Melmed et al., 1983). The patient had hypercalciuria with an average daily urinary excretion of calcium in excess of 7 $\mathrm{mM}$, impaired urinary acidification, and only modest reduction in plasma bicarbonate, which was consistent with RTA-1. His complaints of disabling backache and reduction of height were apparently attributable to advanced demineralization of the thoracic and lumbar vertebrae.

The bony changes in acromegaly used to be attributed to osteoporosis (Kellgren et al., 1952; Hamwi et al., 1960) but this view has been questioned following studies using quantitative densitometry of bone radiograms (Doyle, 1967; Rigg et al., 1972; Aloia et al., 1972; Ikkos et al., 1974), histologic study of biopsied bones (Ramser at al., 1966; Doyle, 1967; Riggs et al., 1972), and calcium kinetic studies (Haymovitz and Horwith, 1964; Bell and Bartter, 1967; Nadarajah et al., 1968; Aloia et al., 1972) in patients with active acromegaly. Nowadays osteoporosis is no longer thought to be simply a result of excessive secretion of GH. However, hypercalciuria exceeding 7.5 $\mathrm{mM} /$ day has been observed in 35 to $55 \%$ of patients with active acromegaly (Parfitt, 
1984). Whitehead et al. (1982) observed a marked decrease in height in 4 out of 8 patients with gigantism after 8 to 48 years of follow up. From the age of this patient, the existence of acromegalic features of about 10 years' duration, and lack of gigantism, we could not attribute the observed demineralization of the spine and pelvic bones solely to $\mathrm{GH}$ excess of long duration. Impairment of bone mineralization is well known in RTA, especially in type 2 variation, but skeletal abnormalities are apparently rare in RTA-1 unless complicated by renal insufficiency (Brenner et al., 1982). Despite the presence of nephrocalcinosis, this patient did not have apparent impairment of renal function, so that the observed bone demineralization could not be explained solely by RTA-1. On the other hand, hyperprolactinemia per $s e$, or complicated by estrogen deficiency, has been reported to be associated with osteoporosis (Klibanski et al., 1980) and a combination of hyperprolactinemia and RTA has been reported in one woman (Bar et al., 1975). Hyperprolactinemia, either by itself or in association with RTA, could have contributed to bone demineralization in this patient. The persistence of RTA-1 after normalization of $\mathrm{GH}$ and PRL secretion appears to deny the possibility of RTA-1 as a direct and reversible sequel to excessive secretion of GH and PRL. As certain endocrinopathies such as primary hyperparathyroidism and hyperthyroidism have been known to be associated with RTA-1, presumably as a result of accelerated calcium metabolism (Sebastian et al., 1982), GH excess and hyperprolactinemia appear to have contributed to the development of RTA-1 by a similar mechanism. RTA further enhanced calciuria and the latter conceivably accelerated RTA. In other words, these abnormalities appear to have led, in a vicious cycle, to progressive bone demineralization in this patient. This cycle, if not interrupted, could have led to the development of kyphosis as reported by Whitehead et al. (1982).

\section{Acknowledgement}

The author is thankful to Dr. Yosiaki Osamura for GH- and PRL-staining of the pituitary tissue with immunoperoxidase.

\section{References}

Aloia, J. F., M. S. Roginsky, J. Jowsey, C. S. Dombrowski, K. Shukla and S. H. Cohn (1972). Skeletal metabolism and body composition in acromegaly. J. Clin. Endocrinol. Metab. 35, 543-551.

Bar, R. S., E. L. Mazzaferri and W. E. Malarkey (1975). Primary empty sella, galactorrhea, hyperprolactinemia and renal tubular acidosis. Am. J. Med. 59, 863-866.

Bell, N. N. and F. C. Bartter (1967). Studies of ${ }^{47} \mathrm{Ca}$ metabolism in acromegaly. J. Clin. Endocrinol. Metab. 27, 178-184.

Brenner, R. J, D. B, Spring, A. Sebastian, E. M. McSherry, H. K. Genant, A. J. Palubinskas and R. C. Morris, Jr. (1982). Incidence of radiologically evident bone disease, nephrocalcinosis, and nephrolithiasis in various types of renal tubular acidosis. New. Engl. J. Med. 307, 217-221.

Broyer, M. (1977). Tubular syndrome. In : Nephrology (J. Hamberger, J. Crosnier and J-P Grünfeld eds), Wiley-Flammarion, New York, p. 192.

Doyle, F. H. (1967). Nonparathyroid endocrine bone disease. Proc. Roy. Soc. Med. 60, 11311132 .

Hamwi, G. J., T. G. Skillman and K. C. Tufts (1960). Acromegaly. Am. J. Med. 29, 690699.

Haymovitz, A. and M. Horwith (1964). The miscible calcium pool in metabolic bone disease in particular, acromegaly. J. Clin. Endocrinol. 24, 4-14.

Ikkos, D. G., K. Ntalles, C. Velentzas and P. Katsichtis (1974). Cortical bone mass in acromegaly. Acta Radiol. [Diagn] (Stockh) 15, 134-144.

Kellgren, J. H., J. Ball and G. K. Tutton, Jr. (1952). Articular and other limb changes in 
acromegaly; clinical and pathological study of 25 cases. Quart. J. Med. 21, 405-424.

Klibanski, A., R. M. Neer, I. Z. Beitins, E. C. Ridgway, N. T. Zervas and J. W. McArthur (1980). Decreased bone density in hyperprolactinemic women. New Engl. J. Med. 303, 1511-1514.

Melmed, S., D. G. Braunstein, E. Horvath, C. Ezrin and K. Kovacs (1983). Pathophysiology of acromegaly. Endocr. Rev. 4, 271-290.

Nadarajah, A., M. Hartog, B. Redfern, N. Thalassinos, A. D. Wright, G. F. Joplin and T. R. Fraser (1968). Calcium catabolism in acromegaly. Brit. Med. J. 4, 797-801.

Okuda, H., S. Fujii and Y. Kawashima (1965). A direct colorimetric determination of blood ammonia. Tokushima J. Exp. Med. 12, 1123.

Parfitt, A. M. (1984). Bone as a source of urinary calcium - osseous hypercalciuria. In : Hypercalciuric states. Pathogenesis, conse- quences, and treatment (F. L. Coe ed), GruneStratton, Orlande, Florida, p. 354-356.

Ramser, J. R., H. M. Frost and R. Smith (1966). Tetracycline-based measurement of the tissue and cell dynamics in rib of a 25 -year-old man with active acromegaly. Clin. Orthop. 49, 169172.

Riggs, B. L., R. V. Randall, H. W. Wahner, J. Jowsey, P. J. Kelly and M. Singh (1972). The nature of the metabolic bone disorder in acromegaly. J. Clin. Endocrinol. Metab. 34, 911-918.

Sebastian, A., H. N. Hulter, I. Kurtz, T. Maher and M. Schambelan (1982). Disorders of distal nephron function. Am. J. Med. 72, 289307.

Whitehead, E. M., S. M. Shalet, D. Davies, B. A. Enoch, D. A. Price and C. G. Beardwell (1982). Pituitary gigantism: A disabling condition. Clin. Endocrinol. 17, 271-278. 